\title{
Gender Disparity in Access to Agricultural Resources and Services (Evidence from Arba Minch Zuria Woreda of Southern Ethiopia)
}

\author{
Agidew Abebe \\ College of Agricultural Science, Arba Minch University, Arba Minch, Ethiopia
}

\section{Email address:}

agidew.abebe@gmail.com

\section{To cite this article:}

Agidew Abebe. Gender Disparity in Access to Agricultural Resources and Services (Evidence from Arba Minch Zuria Woreda of Southern Ethiopia). Agriculture, Forestry and Fisheries, Vol. 6, No. 6, 2017, pp. 184-187. doi: 10.11648/j.aff.20170606.11

Received: April 14, 2017; Accepted: May 8, 2017; Published: October 17, 2017

\begin{abstract}
The study was conducted at Arba Minch Zuria Woreda. The main objective of this study was focused on the assessment of gender disparity in access to agricultural resources and services. This study covers the two Kebeles from the Arba Minch Zuria Woreda. From those two Kebeles 104 respondent household sware included in this study. The data were analyzed through simple descriptive statistics (frequency, percentage and mean) and inferential statistics (independent $\mathrm{t}$-test). The result showed that male respondents had better mean land holding and irrigated land size than that of female respondents. Male respondents had better access to irrigation water than female respondents. The reasons behind this were in the study area the irrigation was labor and capital intensive practice. Therefore, those who have low family labor have less access to use irrigation water. Motorized water pump was less adopted by both male and female respondents. The reason was its high purchasing and maintenance cost. Therefore, it was not afforded by most of the farmers. The result also shows that male farmers have better access to extension training than female farmers. In the study area both male and female respondent farmers were affected by different constraints in access to productive resource. The finding suggested that, the governmental and non-governmental organization should give empathies for adult education and extension training for women. It improves women's awareness and understanding about different agricultural resources and improved farm technologies.
\end{abstract}

Keywords: Gender, Disparity, Resources, Services, Descriptive Statistics, Inferential Statistics and Independent T-Test

\section{Introduction}

In rural areas, where agriculture is still the main source of income, land remains the key household asset. Access to land is a basic requirement for farming and control over land is synonymous with wealth, status and power in many areas. Strengthening women's access to and control over land is an important means of raising their status and influence within households and communities. Improving women's access to land and security of tenure has direct impacts on farm productivity, but can have far reaching implications for improving household welfare as well. Strengthening land ownership by women in Nepal, for example, is linked with better health outcomes for children [1].

In Africa's agricultural sector, women are responsible for producing $80 \%$ of the food, as opposed to men who tend to engage more in income generating activities such as cash crop production, perhaps because of their responsibility of availing food for the family. Despite this essential contribution to household food production and provision, access to resources such as appropriate technologies, modern farming methods, markets, credit and extension services for women is limited [5].

Gender of household heads, as revealed in a study conducted in Ethiopia, influenced participation in governmental extension programs, with male-headed households taking dominance (75\%). Factors such as age, farm size, religion, education level and income were reported to have a significant effect on accessibility to extension services by women [8].

Gender is a key factor in explaining the variation in access to social services in rural low-income communities in Uganda; it would therefore be useful to separately analyze accessibility of male- and female-headed households to 
social support services in sweet potato production [2].

Men and women farmers play important roles in agriculture throughout the world. Particularly striking is that women's contribution to farm work is as high as between

$60 \%-90 \%$ of the total farm task performed [4]

The fact that women are often involved in household chores gives them little time to receive extension services, unlike their male counterparts. Little or no detailed individual information on empirical studies on women sweet potato farmers' access to and use of agricultural information, credit and extension services in Uganda is available. The lack of such information is therefore an obstacle to reducing gender bias in access to social services and consequently hinders poverty reduction and economic development programs. The contribution of women to food security cannot be overlooked. There is a need for access to proper and relevant agricultural information, credit and extension services if sweet potato production is to be increased. An understanding of gender differences in accessibility may go a long way in explaining barriers to technology adoption and factors facilitating sweet potato production [9].

Women in developing countries like Ethiopia are generally silent and their voice has been quite by economic and cultural factors. Economic and cultural factors coupled with institutional factor dictate the gender based division of labor; rights, responsibilities, opportunities and access to and control over productive resources are some of the area of gender disparities [7].

In Arba Minch Zuria Woreda there is no study conducted on the gender disparity in access to agricultural resources and services. Therefore this study was focused on the assessment the gender disparity in access to agricultural resources and services at Arba Minch Zuria Woreda of Gamo Gofa Zone.

\section{Objectives of the Study}

a. To examine the disparity between men and women farmers in access to agricultural resources.

b. To examine the disparity between men and women farmers in access to agricultural services.

\section{Materials and Methods}

In this study, a multi-stage sampling procedure was employed for the selection of Woreda, sample Kebeles and respondent households. In the first stage, the Woreda was selected purposively. In the second stage, out of 29 rural Kebeles, 2 sample Kebeles (Chano Mile and Shara) were randomly selected through simple random sampling method. In the third stage, the total households found in the 2 sample Kebeles were stratified into two strata (Male and female headed households) and the total sample of 104 respondent farmers were included in this study. The respondents for the two strata were selected from population frame through systematic sampling technique.

The data were collected from both primary and secondary data sources. Primary data were collected by using structured questionnaire from respondent households whereas the secondary data was collected from published and unpublished sources. The data were analyzed through simple descriptive statistics (frequency, percentage and mean) and inferential statistics (independent t-test).

\section{Result}

This section presents and discusses the results of the analysis that has been conducted to address specific objectives of the study. The section includes the respondents' access to agricultural resources and services.

\subsection{Access to Agricultural Resources}

\subsubsection{Access to Farm Land}

The results in Table 1 show that the mean land holding size of the total respondents was 1 hectare. However, the men respondents' was 1.23 hectares and that of women respondents' was 0.76 hectares. The t-value result also revealed that the mean land holding of men farmers had significantly larger than that of women farmers at $5 \%$ significance level. This mean difference also shows that male respondents had better access to land than women respondents.

Table 1. Land holding size of respondents' household.

\begin{tabular}{llllllll}
\hline Land & Men & \multicolumn{5}{c}{ Women } & \multicolumn{2}{c}{ Total } & \multirow{2}{*}{ t-value } \\
\cline { 2 - 6 } Size & $\mathbf{N}$ & $\mathbf{\%}$ & $\mathbf{N}$ & $\mathbf{\%}$ & $\mathbf{N}$ & $\mathbf{\%}$ & \\
\hline$\leq 0.5$ & 10 & 16.7 & 26 & 50 & 36 & 33.3 & \\
$0.51-1$ & 10 & 16.7 & 7 & 10 & 17 & 13.3 & \\
$1.1-1.5$ & 32 & 66.6 & 19 & 40 & 51 & 53.3 & \\
Mean & 1.23 & & 0.76 & & 1 & & $5.67 * *$ \\
\hline
\end{tabular}

**, significance at $5 \%$ level P-value $=0.045$

\subsubsection{Access to Irrigation Water}

The result in the table 2 show that from the total male respondents $63.3 \%$ had access to irrigation water while from the total female respondents $83.3 \%$ hadn't access to irrigation water. This result also revealed that male respondents had better access to irrigation water than female farmers. The reason behind this was in the study area the irrigation practice is labor and capital intensive practice. Therefore, those female who have physically weak when compared with men and those who have low family labor had less access to use irrigation water.

Table 2. Access to irrigation water.

\begin{tabular}{lllllll}
\hline \multirow{2}{*}{$\begin{array}{l}\text { Access to } \\
\text { irrigation water }\end{array}$} & Men & \multicolumn{3}{c}{ Women } & Total \\
\cline { 2 - 7 } & $\mathbf{N}$ & $\mathbf{\%}$ & $\mathbf{N}$ & $\mathbf{\%}$ & $\mathbf{N}$ & $\mathbf{\%}$ \\
\hline No & 22 & 36.7 & 42 & 83.3 & 64 & 55 \\
Yes & 30 & 63.3 & 10 & 16.7 & 40 & 45 \\
\hline
\end{tabular}

\subsubsection{Irrigated Land Holding Size}

The results in table 3 show that the mean irrigated land size of men respondents' had 0.85 while that of women respondents had 0.27 . The $t$-value result also revealed that the mean irrigated land holding of men farmers had significantly larger than that of women farmers at $5 \%$ 
significance level. This mean difference also shows that men respondents had better access to irrigated land than women respondents.

Table 3. Irrigated land holding size.

\begin{tabular}{|c|c|c|c|c|c|c|c|}
\hline \multirow{2}{*}{$\begin{array}{l}\text { Irrigated } \\
\text { land size }\end{array}$} & \multicolumn{2}{|c|}{ Men } & \multicolumn{2}{|c|}{ Women } & \multicolumn{2}{|c|}{ Total } & \multirow{2}{*}{ t-value } \\
\hline & $\mathbf{N}$ & $\%$ & $\mathbf{N}$ & $\%$ & $\mathbf{N}$ & $\%$ & \\
\hline$\leq 0.5$ & 23 & 43.3 & 45 & 83.3 & 68 & 63.3 & \\
\hline $0.51-1$ & 2 & 6.7 & 1 & 3.3 & 3 & 5 & \\
\hline $1.1-1.5$ & 27 & 50 & 6 & 13.3 & 33 & 31.7 & \\
\hline Mean & 0.85 & & 0.27 & & 0.56 & & $7.34 * *$ \\
\hline
\end{tabular}

**, significance at $5 \%$ level P-value $=0.023$

\subsubsection{Use of Motorized Water Pump}

The results in table 4 show that from the total men respondents $76.7 \%$ and from the total women respondents $83.3 \%$ hadn't used motorized water pump for their irrigation practices. This technology is crucial to lift water from different sources and apply on the farm. The supplemental irrigation also improves crop productivity. But this was less adopted by both groups. The reasons behind this were its high purchasing, cost of spare part and maintenance cost. Therefore, it was not afforded by most of the farmers.

Table 4. Use of motorized water pump.

\begin{tabular}{lllllll}
\hline Have motorized & \multicolumn{2}{c}{ Men } & \multicolumn{3}{c}{ Women } & Total \\
\cline { 2 - 7 } water pump & $\mathbf{N}$ & $\mathbf{\%}$ & $\mathbf{N}$ & $\mathbf{\%}$ & $\mathbf{N}$ & $\mathbf{\%}$ \\
\hline No & 44 & 76.7 & 47 & 83.3 & 91 & 80 \\
Yes & 8 & 23.3 & 5 & 16.7 & 13 & 20 \\
\hline
\end{tabular}

\subsubsection{Livestock Holding Size}

The results in table 5 show that the mean livestock holding of male respondents' was 3.75 and that of female respondents' was 3.38. The t-value result also revealed that the mean livestock holding of men farmers had significantly larger than that of women farmers at $10 \%$ significance level. This mean difference also shows that men respondents had better livestock holding than women respondents.

Table 5. Number of livestock holding.

\begin{tabular}{llllllll}
\hline $\begin{array}{l}\text { Number of } \\
\text { livestock }\end{array}$ & Men & \multicolumn{5}{c}{ Women } & \multicolumn{2}{c}{ Total } & \\
\cline { 2 - 6 } & $\mathbf{N}$ & $\mathbf{\%}$ & $\mathbf{N}$ & $\mathbf{\%}$ & $\mathbf{N}$ & $\mathbf{\%}$ & t-value \\
\hline$\leq 4$ & 42 & 73.3 & 42 & 83.3 & 84 & 78.3 & \\
\hline $5-8$ & 10 & 16.7 & 10 & 16.7 & 20 & 21.7 & \\
Mean & 3.75 & & 3.38 & & 3.5 & & $4.35^{*}$ \\
\hline
\end{tabular}

*, significance at $5 \%$ level. P-value $=0.087$

\subsection{Access to Agricultural Services}

\subsubsection{Access to Extension Training}

The results in table 6 show that out of the total men respondents $46.7 \%$ did attended while from the total women respondents $36.7 \%$ did attended on training that focused on agricultural related practice. This result also shows that men farmers had better access to extension training than women farmers. Because of women farmers have less contact and communication with development agents. The reason behind this is due to cultural influence most of rural women have no access to contact with extension agents.

Table 6. Attended on training.

\begin{tabular}{lllllll}
\hline \multirow{2}{*}{$\begin{array}{l}\text { Attended on } \\
\text { Training }\end{array}$} & Man & \multicolumn{3}{c}{ Women } & Total \\
\cline { 2 - 7 } & $\mathbf{N}$ & $\mathbf{\%}$ & $\mathbf{N}$ & $\mathbf{\%}$ & $\mathbf{N}$ & $\mathbf{\%}$ \\
\hline No & 22 & 53.3 & 36 & 63.3 & 58 & 58.3 \\
Yes & 30 & 46.7 & 16 & 36.7 & 46 & 41.7 \\
\hline
\end{tabular}

\subsubsection{Access to Farm Credit}

The results in table 7 show that out of the total men respondents $96.7 \%$ and from the total women respondents $86.7 \%$ didn't use credit. This result also shows that the use of credit from microfinance institution was very low by two groups.

Table 7. Use of credit by the respondents' household.

\begin{tabular}{lllllll}
\hline \multirow{2}{*}{$\begin{array}{l}\text { Use of } \\
\text { credit }\end{array}$} & Men & \multicolumn{3}{c}{ Women } & \multicolumn{3}{c}{ Total } \\
\cline { 2 - 7 } & $\mathbf{N}$ & $\mathbf{\%}$ & $\mathbf{N}$ & $\mathbf{\%}$ & $\mathbf{N}$ & $\mathbf{\%}$ \\
\hline No & 51 & 96.7 & 48 & 86.7 & 99 & 91.7 \\
Yes & 1 & 3.3 & 4 & 13.3 & 5 & 8.3 \\
\hline
\end{tabular}

\subsubsection{Access to Local Agricultural Markets}

The information gathered respondents show that farmers have well access to local market to sale their product. In the area, crop products especially Banana, Mango, Cotton and Vegetables especially Onion, Hot pepper and Tomato growing as a Cash crop and supplied to assemblers who are: better-off farmers, primary cooperatives and privet merchants. Fruit crops (Banana and Mango) collected by those assemblers and supplied at different regions large markets (Hawassa, Adama, Dire Dawa and Mekele and Central market at Addis Ababa). On the other side, farmers also engaged in fatting of livestock especially Oxen and supplied at their local markets. Therefore, in the study area both groups have equal access to local market.

\subsubsection{Access to Roads and Transportation}

The result obtained from respondents show that the Asphalt road from Addis Ababa -Arba Minch - Jinka crosses the three sample Kebeles. Consequently, the agricultural products from these Kebeles without any problem loaded on the truck and send to different large markets of the country. Therefore, in the study area both groups have equal access to roads and transportation.

\section{Discussion}

The finding shows that women farmers had less access farm and irrigated land when compared with men farmers and both had less adopted irrigation technology and low use of farm credit. In agreement with this finding, the evidence illustrating the inequalities in access to land is overwhelming and straddles continents and cultural contexts. In regions, such as Latin America, where private property systems are the norm, inheritance is the most frequent source of transfer of ownership of land. As a result of customs, women are much less likely to inherit. In addition, there is usually male 
privilege in marriage, and state programs of land redistribution (land reform) have tended to be biased towards men [3].

None of the female-headed households irrigated their sweet potato fields and only $10 \%$ of the male headed households practiced irrigation mainly in sweet potato nurseries. Irrigation was mostly performed by hand using water cans. Generally, few households ( 8.60 and $9.43 \%$ of male- and female-headed households, respectively) received any form of agricultural information related to sweet potato production, marketing or value addition in the last 12 month. This low access to agricultural information regarding sweet potato farming is worrying, because it can result in low technology adoption. This implies that most farmers continue to use indigenous farming methods for crop production, a factor that may explain the low on farm root yields and high losses due to insect pest damage. More female-headed households lacked access to credit (26.4\%) compared to $15.1 \%$ of male-headed households [10].

In sub-Saharan Africa, where communal property regimes are more common, community heads tend to assign land to males, not females, and where private property prevails cultural norms generally dictate that men are the owners of land while women gain access to land through their relationship with a male relative: father, husband, brother or other [6].

\section{Conclusion}

The mean land holding size of men respondents' was 1.23 hectares and that of women respondents' was 0.76 hectares. This mean difference also shows that male respondents had relatively better access to land than female respondents.

The result also shows that male respondents have better access to irrigation water. The reasons behind this were in the study area the irrigation was labor and capital intensive practice. Therefore, those female respondents have physically weak when compared with males and those who have low family labor have less access to use irrigation water.

The mean irrigated land size of men respondents had 0.85 while that of women respondents had 0.27 . This result also implies that males have relatively better irrigated land than female farmers.

Motorized water pump is crucial to lift water from different sources and apply on the farm. The supplemental irrigation also improves crop productivity. But this was less adopted by male and female respondents. The reason was its high purchasing and maintenance cost. Therefore, it was not afforded by most of the farmers.

The mean livestock holding of male respondents' was 3.75 and that of female respondents' was 3.38. This result also shows that two groups have relatively the same livestock holding size.

The result also shows that male farmers have better access to extension training than female farmers. Because of female farmers have less contact and communication with development agents. And also the use of credit from microfinance institution was very low by two groups.

\section{Recommendation}

a. The governmental and non-governmental organization should give empathies for adult education and extension training for women. It improves women's awareness and understanding about different productive resources and improved farm technologies.

b. Concerned bodies should give special attention for women farmers about credit services because it improves their capability and empower them.

\section{References}

[1] Allendorf K, (2007). Do women's land rights promote empowerment and child health in Nepal? World Development, Vol. 353 (11): 1975-1988.

[2] Bakeera SK, Pariyo G, Petzold M, Galea S, Wamala SP. (2012). Associations between Socioeconomic factors and social capital amongst child caregivers in Eastern Uganda. Rev Econ Financ 2012, 1:51-62.

[3] Deere, C. D. and M. Leon. (2003). The Gender Asset Gap: Land in Latin America. World Development, Vol. 31 (6): 92547.

[4] Damisa MA, Yohanna M (2007). 'Role of rural women in farm management decision making process: Ordered probit analysis', World J. Agric. Sci.; 3(4): p. 543, IDOSI publication

[5] Ibnouf FO, (2012). The value of women's indigenous knowledge in food processing and preservation for achieving household food security in rural Sudan. J Food Res 2012, 1:238-253.

[6] Lastarria, Cornhiel, S. (1997). Impact of privatization on gender and property rights in Africa. World Development, Vol. 25: $1317-1333$.

[7] Mukuria, A. Aboulfia. C, Themme, A. (2005). The concept women's Health: Results from the Demographic and Health surveys 1994-2001. Comparative Reports No. 11. coverton, maryland: ORC Meuro.

[8] Okwu OJ, Umoru BI, (2009). A study of women farmers' agricultural information needs and accessibility: a case study of Apa Local Government.

[9] Okonya JS, Syndikus K, Kroschel J, (2001). Farmers' perception of and coping strategies to climate change: evidence from six Agro-ecological zones of Uganda. J AgricSci 2013, 5:252-263.

[10] Okonya and Kroschel, (2014). Gender differences in access and use of selected productive resources among sweet potato farmers in Uganda. Agriculture \& Food Security $\mathrm{http}: / /$ www.agricultureandfoodsecurity.com/content/3/1/1. 